\title{
Analysis and Review of Key Factors at PPP Project Renegotiation
}

\author{
Shulian $\mathrm{Wu}^{1, \mathrm{a}}$ and Yiying Yang ${ }^{1, \mathrm{~b}^{*}}$ \\ ${ }^{1}$ Department of Construction Management, School of Civil Engineering and Architecture, Zhejiang \\ Sci-Tech University, Hangzhou, Zhejiang, China 310018 \\ a'wushulianwsl@126.com, byyingyang@foxmail.com \\ * The corresponding author
}

Keywords: Public private partnership; Renegotiation; Risk analysis

\begin{abstract}
The public-private partnership(PPP) projects, on one hand are critical in delivering public service, on the other hand have the characteristics propitious to recurrent renegotiation, which renders the extension of construction and concession, and increase of operation cost as well as the governmental responsibility and thus reducing the effectiveness and wasting the public resources. The author aims at review and analysis the risk upon renegotiation and propose several risk aversion strategies by exploring the key influencing factors of renegotiation based on several typical PPP renegotiation cases.
\end{abstract}

\section{Introduction}

Public Private Partnerships (PPPs) are arrangements between public and private entities for the delivery of infrastructure service and are seen as a way of developing respective advantages, aiming at extending or leveraging better budget funding through efficiency gains and spreading the risk [1].

However, the pasting years also sees a large number of renegotiation among those PPP contracts and thus slowing down the efficiency of those projects. Bitran points out that the number of renegotiation in Columbia during 1993-2010 has loomed large as 7 times of that in Chile or Peru, among which were associated to additional investments in infrastructure that were not previously included, suggesting poor project management in conducting comprehensive investment research and targeting the scope of projects at interest[2]. Another study also indicates that most concessions have been renegotiated at least once. Among renegotiated concessions, the first change has occurred on average only two years after the contracts were signed and each contract was renegotiated on average once a year. The costs of such renegotiation have included more than 7 billion dollar fiscal cost, $20 \%$ average cost increases in concessions term, higher toll prices, greater risks faced by the State and delays in construction deadlines[3].

By the end of 2015, there were 2,125 PPP projects approved by the National Development and Reform Commission, with the total investment of 2.5 trillion yuan; and more than 230 PPP projects approved by Ministry of Finance with investment of about 8,400 billion yuan [4]. China's PPP projects has soared in the last two decades.

However, PPP projects have the characteristics propitious to recurrent renegotiation which allows the parties to respond to unanticipated events and changes in the needs of the parties [1]. According to Ministry of Finance of the People's Republic of China, Public-Private Partnerships Center (CPPPC), the newly established PPP projects rolls up to $91 \%$ of the total PPP projects with the amount of 7.57 Trillion RMB, showing the majority of those new PPP projects in current market. Moreover, 5,542 of them (about $78 \%$ of the total) are in the program identification phase[5]. The identification and preparation phase are key to the feasible study, contractor negotiations and thus avoid further renegotiation. The lack of identifying multiple risks, insufficient research and study could end up with the renegotiation, therefore, It's of great value to have a better understanding of those key factors in PPP projects. 


\section{Concept of Renegotiation in PPP Projects}

PPP renegotiation refers to the separate views on allocation of profits or financial ratios between the public sector and the provide sector. It usually arises from several issues including the unseasonable contract or the change of the outer environment after the concession was offered.

José Luis Guasch purposes that renegotiation are mainly a change in the risk matrix assignment in the conditions of the contract, or in project scope if not regulated in the contract. Usually renegotiation results improvement of the terms of the operator or investors, reduction of efficiency, reduction of quality for users and adverse financial impact, including increases indirect and contingent liabilities [6]. As Guasch indicates, many projects have been renegotiated overtime. The factors that lead to renegotiation could be concluded as any or a combination of the following: lower than expected revenue, higher than expected costs, delays, variations in contractual specifications and disagreements between the parties as to cause and effect of actions or inaction. Any of these could give rise to a call for amending the terms of the Concession Agreement to better reflect the project realities [7].

\section{Analysis for Critical Factors of Renegotiation in PPP Projects}

Compliance Risk. The change in law risk leads to the shifts in project liabilities, validity of the contract, product and service fee, and might eventually result in the failure of the project. One of the famous examples is the BOT project in water and sanitation sector located in Jiangsu Province. which was planned to kick off in 2002, however, the water company began to default the waste water company treatment fee after a newly published law: Notice of State Council[2002, 43]: Administration over fixed income investment of foreign investors. The private company had to arise the renegotiation in terms of the return rate[8].

Management Risk. Risk of poor public decision-making process is generally resulted from several factors such as government bureaucracy, non-standard decision-making procedure, information asymmetry, and lack of relative experience, operation ability and feasibility study, which leads to decision-making error and long process[9]. There are many examples of PPPs for the construction and operation of highways that failed due to the lack of preparation and experience from government side. One example is the waste-water treatment plant project in Qingdao. During the negotiation phase, the government and project company had reached an agreement on a certain waste-water treatment fee, nevertheless, the government later found out the contracted price is relatively higher above the average market price and was forced to arise renegotiation since the project began[10]. In this case, private company took advantage of the government' failure in valuation and prediction to the project, which also end up with the government's long decision process.

Credit Risk. Government credit risk is referred to the risk of government actions that may endanger a project. Primary credit risk includes the government's refusal to fulfill certain contractual obligations considering its own interests or other factors. A French-China water supply plant concession project with 30 years concession period is a typical example. According to the prediction of local water usage volume, the water plant construction scale was determined to be more than $60,000 \mathrm{~m}^{3}$ per day, and shall increase annually. However, when the plant was completed, it became clear that the project company was at risk of default as the consumption was only one-third of the forecasting amount provided by investors, lenders, and government. This big gap between realistic volume and expected figure make the contract hard to be fulfilled. What's more, the contract price of waste-water treatment fee was $1.25 \mathrm{yuan} / \mathrm{m}^{3}$, and shall fluctuate with exchange rate, CPI, external environment and other relative factors. However, the actual water treatment price was 1.20 yuan $/ \mathrm{m}^{3}$, and had not increased since May $1^{\text {st }}, 1999$, which left the project to be in an endless renegotiation[11].

Revenue Risk. Revenue risk is likely to be encountered when a project does not reach its expected goals over the period of the concession and not be able to maintain principal or capture profits. For example, a garbage incineration power plant project in Tianjin, whose government 
made a series of measures to motivate companies, one of which was promising that a subsidy would be offered in case the private company cannot achieve break-even and obtain greater return. Nevertheless, the project company still had to bear the risk of insufficient market income since the government did not mention a specific amount of money provided[8]. Besides, the price elasticity of PPP projects is relatively low, which means the operating revenue might not meet the expected goal especially when the price was set to be either too high or too low.

Project Uniqueness Risk. Risk of project uniqueness is an later-formed business competition environment due to the reason that government or other companies build or rebuild another similar project. The occurrence of this risk usually accompany with market income risk, demand risk, credit risk, etc., which may have a bad influence on the project. The bridge project in Minjiang shed a light on our understanding of it, in which the government promised that the bridge would be the only entrance for the motor vehicles to enter Fuzhou city from the south. They also made an agreement by promising an 18 percent compensation each year, including foreign debts in case they cannot secure the project payment. However, a similar project, the second ring road third phase of Fuzhou city, went into service on May 16, 2004, which caused a large amount of vehicles entering the city without passing the previous tollbooth of Minjiang bridge[12]. In the end, the company had to initiate arbitration while their earnings fell sharply and the government welshed on its promises.

Market Demand Risk. Market demand risk refers to the big differences between actual demand and the expected one due to the changes of overall financial environment, law, populations and other factors that would made a tremendous impact on it.

Government Corruption Risk. Risk of government corruption is seen when government officials' illegal behaviors such as taking bribes, embezzling public money and so on, which may increase the possibilities of government defaults. A Hong Kong invested water treatment plant is a typical example. According to their agreement, the plant can achieve $18.50 \%$ rate of return on investment (ROI) over 2-4 years; $21 \%$ ROI over 5-14 years; and 11\% ROI over 15-20 years. However, a later report indicates that this term was unreasonable owing to the excessively high ROI based on the water treatment situation of the city during that period. Committing to the agreement of high return rate, the state water company had to pay 2.50 yuan per ton to water treatment plant while the average price in the city was 1.40 yuan per ton. By 2000, state water company had lost two billion yuan and finally raised objection towards the agreement. After several months of intense renegotiation, they reached a new agreement at the end of 2000: state water company buy 50\% stake in water treatment company, and the ROI is decreased to $14 \%$. For the changes like that, water company can save the payment of more than two billion yuan, and it also reflects one fatal error that the local government did not seriously estimate the potential water treatment volume based on the actual condition of the period, which is usually associate with the corruption[13].

The above-mentioned cases summarized most of risks that occurs during PPP project negotiation, it's usually not only single one of them, but a combination of them that results in the renegotiation.

\section{Risk Aversion Strategies}

Given the problems above-mentioned and the major risks involved in concession contracts, the author proposes five risk aversion strategies for the PPP projects.

Full-fledged Legal System. The changes in macro political and economic environments are the two main factors that bring about renegotiation since they reveal the volatility of local policy. To a certain extent, it hurts the trust of investors on government. When this kind of issue occurs, the government should take effective measures in time for providing private company a stable political and investing environment.

Clear and Formal Agreement. Renegotiation is most likely to generate in three phases involving procurement, construction and operation of the project during the performance window of concession agreement. Therefore, it is important for PPP agreements between local government 
and private company to be sufficiently clear and formal. Meanwhile, government should focus on various performance indicators rather than solely on social demands since defining performance indicators can effectively reduce the chances of renegotiation. Moreover, having identified renegotiation provision in contracts for reference can also reduce the opportunities of further dispute over the structure of the procedure. At last, the clarity of authorization means the sponsor should identify which sector is taken the bargaining right, and should have a clear understanding of the scope and duration of the authorization including the general terms about construction and operation.

Good Cooperation Relationship. In the PPP project, a long-lasting cooperation relationship should be maintained between government and private sector. During the construction and operation stages, good communication is essential for the smooth implementation of the project due to two seasons.

Multiple Supervisory Systems. During the construction and operation phases, public sector should establish efficient legislative and supervisory systems including the usage of various kinds of regulatory instruments to strengthen supervision and management. Those measures should ensure the full effectiveness of bidding competition. In sum, the whole process should be supervised to ensure the competition for the use of the public is open, fair and free from bribery and nepotism and thus decreasing the chances of renegotiation.

Reasonable Risk Allocation System. Establishing a systemic way, of which the risk appetite are moderately controlled and met the standard of each side, could ensure the profits for every sectors involved. The designing of a robust project management protocol mainly consists of two parts: firstly, prioritize sub-projects, and secondly, categorize risks among each segment, review and analysis those risks in a regular basis.

\section{Conclusions}

In general, governments are responsible for project screening, cooperation with private investors, and projects' quality control. Public sector authority should maintain a good image of the government which bears on its reputation in the public and continuously contributes to its work efficiency and.an stability of investment environments, which can reduce the chance of renegotiation, and attracting private participation to deliver infrastructure and other public services. As a cooperator, government should set up an effective communication mechanism to ensure the smooth implementation of the project. As a supervisor, government should be strict to employ financial and quality supervision.

For private sectors, conducting in-depth analysis on local market is key to achieve a good rate of return. Besides, comprehensive research and objective evaluation of governmental responsibilities and regulatory support also plays a significant role in PPP investments. At last, a formal and clear written agreements from each stakeholder should be maintained.

In sum, the better understanding of responsibilities, risk appetite together with a risk aversion strategy and a robust legislation and enforcement system would minimize the risks and offer an optimized solution to achieve public and private win-win result.

\section{Acknowledgements}

This research was financially supported by the Ministry of Education of China, Project in Humanities and Social Sciences. (No.13YJA630105)

\section{References}

[1] J. Delmon: Private Sector Investment in Infrastructure, Project Finance, PPP Projects and Risk, second ed (Kluwer Law International, The Netherlands 2009), p. 7.

[2] B. Eduardo, V. Marcelo: Benefits and Costs in Public Private Partnership: Transport 
Infrastructure Projects in Latin America. Facultad de Ingeniería y Ciencias, Universidad Adolfo Ibañez.(2012)

[3] E. Bitran, S. Nieto-Parra and J.S. Robledo: OECD Developing Centre, Working Paper No. 317 (2013)

[4] Information on http://www.ndrc.gov.cn/xwzx/xwfb/201512/t20151216_767643.html. (In Chinese)

[5] Information on http://www.cpppc.org/ppptpbd/3063.jhtml (In Chinese)

[6] J.L. Guasch, D. Benitez, I. Portabales and L. Flor: PPP for Transport Infrastructure Renegotiations, How to Approach Them and Economic Outcomes (Arlington, USA, October 27-28, 2014 ) Discussion Paper No. 2014-18

[7] Department of Economic Affairs, Ministry of Finance, Government of India(DEA): Developing a Framework for Renegotiation of PPP Contracts Final Report.(2014)

[8] S.Q. Wang: Asian Infrastructure Congress (Hong Kong, Nov 29-30, 2006) keynote speech

[9] X. Qi, Y.J. Ke and S.Q. Wang: China Soft Science Magazine (2009) No.5, p.107 (In Chinese)

[10]Asian Development Bank: Relative suggestions for and problems on the promotion of Marketization of China's urban water industry (PPP) (2005)

[11]Information on http://news.h2o-china.com/finance/information/114651029478620_1.shtml (In Chinese)

[12] Information on http://news.stock888.net/040804/101,1317,1009454,00.shtml (In Chinese)

[13]Information on http://www.86ne.com/Jnhb/200409/Jnhb_38197.html (In Chinese) 